\title{
STUDENTS” PERCEPTION OF THE USE OF “ENGLISH PHRASAL VERB” VIDEOS TO ENHANCE STUDENTS' INDEPENDENT LEARNING SKILL
}

\author{
Haryanti \\ Syarif Hidayatullah State Islamic University of Jakarta, Indonesia \\ (haryanti@uinjkt.ac.id)
}

Received: $6^{\text {th }}$ March 2019; Revised: $22^{\text {th }}$ May 2019; Accepted: $28^{\text {th }}$ June 2019

\begin{abstract}
Independent English Language Learning is very important to do by students, especially students in higher education level, because they are often required to read many English references and use English on many occasions, for example in writing essays. Also, it is because the opportunity or time to learn English in the class is very limited. Therefore, students badly need to learn English independently outside the classroom. This study was designed to investigate the students' perception of the use of "English Phrasal Verb" videos in enhancing their independent learning. There were six participants interviewed and observed to get information about the benefits of using "English Phrasal Verb" videos and the effectiveness of it in training the students to be independent learners. The study found that the students' pronunciation and vocabulary mastery had improved as well as their listening and writing skills due to the use of videos and assignment given. It also revealed that the use of videos had successfully been a trigger for the students to find other English learning videos and learn them independently outside the classroom.
\end{abstract}

Key Words: English language; Independent Learning; Phrasal Verb; English skill

\section{ABSTRAK}

Belajar Bahasa Inggris secara mandiri sangat penting dilakukan oleh siswa, khususnya mahasiswa, karena mereka sering diminta untuk membaca banyak referensi Berbahasa Inggris dan untuk menggunakan Bahasa Inggris di banyak kesempatan, contohnya dalam menulis esai. Selain itu, karena terbatasnya kesempatan atau waktu untuk belajar Bahasa Inggris di kelas, mahasiswa sangat dianjurkan untuk belajar Bahasa Inggris secara mandiri di luar kelas. Penelitian ini didesain untuk menginvestigasi persepsi mahasiswa terhadap penggunaan video tentang frase kata kerja Bahasa Inggris (Phrasal Verbs Videos) dalam meningkatkan kemampuan belajar mandiri mahasiswa. Dalam penelitian ini, terdapat enam peserta yang diwawancarai dan diamati untuk mendapatkan informasi mengenai keuntungan menggunakan video dan keefektifan penggunaan video tersebut dalam melatih mereka menjadi pembelajar mandiri. Penelitian ini menemukan bahwa penguasaan kosakata dan kemampuan pengucapan Bahasa Inggris mahasiswa meningkat begitu juga dengan kemampuan mendengar dan menulis mereka karena penggunaan video yang dimaksud dan tugas yang diberikan. Selain itu, penelitian ini juga menemukan bahwa penggunaan video telah sukses mendorong mahasiswa untuk menemukan video-video belajar Bahasa Inggris lainnya dan untuk mempelajari video-video tersebut secara mandiri di luar kelas.

Kata Kunci: bahasa Inggris; belajar mandiri; frase kata kerja; keterampilan berbahasa Inggris

How to Cite: Haryanti. (2019). Students' Perception of the Use of "English Phrasal Verb" Videos to Enhance Students' Independent Learning Skill. IJEE (Indonesian Journal of English Education), 6(1), 21-29. doi:10.15408/ijee.v6i1.12613 


\section{INTRODUCTION}

Along with the development of technology, there are many innovations related to technology for teaching and learning English created. Not only do these innovations bring positive impacts to the teaching and learning process in the classroom, but they also help students improve their English learning skills outside the classroom. Ahmadi (2008) mentioned that the use of technology could promote activities for students to study independently outside the classroom.

Studying independently outside the classroom is considered important to do if the language mastery is the goal. Moreover, the demands faced by the students in their real-life have increased more and more. Students are required to use English on many occasions, such as in an International youth forum, in applying for a scholarship/ students exchange program, etc. They are also demanded to be able to effectively communicate in English both spoken and written. Meanwhile, in-class learning which is hoped to help students master English seems to be inadequate because it provides students with very limited hours of learning, i.e. three till four hours a week (Lamb, 2002; Mattarima \& Hamdan, 2011; Novera, 2004). Therefore, students are suggested to do independent language learning or outof-class language learning (OCLL, henceforth) to perfect their in-class learning.

Considering the importance of OCLL towards the improvement of students' English ability, teachers' roles in supporting and enhancing the students' independent learning skills are badly needed. Teachers are supposed to be good facilitators who support the students' efforts outside the classroom. There are many things that teachers can do, providing information or resources for learning, for example. Besides, teachers can prepare a huge number of authentic materials for inclass learning, which then can stimulate students to do OCLL (Ahmadi, 2018).

Not only do students need to learn General English and Basic Grammar, but they also need to understand common expressions or words used by native speakers, phrasal verbs, for example, to be able to communicate in English actively. Phrasal verb (PV or PVs, henceforth) is the mixture of a verb and a particle which has a different meaning from each word meaning (Vasbieva, 2015). English Phrasal verbs are necessary to be learned by students because they are very often used by native speakers in their spoken and written communication (ibid., Mart, 2012). 
Also, they are often regarded as complicated material to learn since they are so complex and varied (Vasbieva, 2015; Laufer and Eliasson, 1993 in Castillo, 2017; Mart, 2012). Castillo (2017) mentioned that commonly, teacher listed the PVs learned and asked students to memorize them. She also stated that the method used had made students feel doubt in using PVs and tend to evade employing them (ibid.). Thus, the researcher of this study believes that the use of technology, in this case, is the use of phrasal verb videos taken from YouTube, can be a solution. Moreover, YouTube is considered as a popular website for students.

There has been some previous research conducted to investigate the benefits of using video or other technology in English teaching and learning process. Almurashi (2016) reported that YouTube is effective to help learners comprehend the English lessons, perform better, as well as enhance their English understanding. Mustikawati (2013) also researched to examine the effectiveness of using video in teaching speaking and found that students who used video in learning English had better speaking ability than the ones who used textbook. Besides, Lin and Yang (2011) also investigated the benefits of using Wiki technology to enhance writing skills of the students. They found that the use of Wiki technology had improved students' writing skills and made students learn 'vocabulary, spelling, and sentence structure' from other students' work (ibid., p. 121). It is clear that English teaching and learning using technology bring positive effects for the students.

Furthermore, there are some other previous studies focusing on the benefits of using technology towards the students' independent learning skill. Hennessy, Deaney, and Ruthven (2005) found that technology worked well in training students to be independent or autonomous learners. Parvin and Salam (2015) also reported that the use of technology had allowed students to learn the language in a context which is meaningful and to get understanding by themselves. Both previous studies mentioned here obviously show that technology has a significant role in improving students' independent learning skills. In other words, the use of technology helps students learn and understand something on their own. It also allows students to practice what they have learned either in their real-life or in the digital world, like writing captions on Twitter.

Concerning the importance of PVs understanding, research on PVs, 
especially the one focusing on the method of teaching and learning PVs, needs to be done. Moreover, if the limited number of it has become a consideration, the research on this topic is badly required. This study was conducted to examine the students' perception of the use of phrasal verb videos in learning. It focused on investigating the benefits of using the videos and the effectiveness of using them in enhancing the students' independent language learning skills, using lecturer's observation sheet and written interview. To achieve the purposes of the research, two research questions were created to know the students' perception of the use of PVs videos, i.e.: 1)What are the benefits of using English Phrasal Verb videos in learning English?; 2) Is the use of English Phrasal Verb videos effective to enhance students' independent language learning skills?;.

\section{METHOD}

It is qualitative research in the form of a case study. It investigated the benefits of using English Phrasal Verb Videos in learning English and the effectiveness of using the videos to improve students' independent language learning skills based on the students' perception. The participants in this study were chosen through a typical sampling procedure. The researcher selected participants who had experience which was similar to the focus of the research (Dornyei, 2007). The participants involved were six second-semester students majoring in International Relation at an Indonesian university and taking General English course. They aged 19 to 20 years old and had intermediate-upper intermediate English proficiency levels. Pseudonyms were used in this study to maintain the students' confidentiality.

To collect the data, there were two instruments used in this study, those are observation sheet and written interview. The participants taken parts were given six videos taken from Rachel's English YouTube channel. They needed to watch, read, write, and understand the meaning of the phrasal verbs learned as well as the sentences provided in each video every single week, starting from week 2 till week 7 . During these six weeks, the researcher observed and checked the students' work. Then, in week 8 , the participants were required to submit their notes and to answer the interview questions. There were 10 questions given in the interview.

There were six themes used in the analysis process, i.e. improve the student's vocabulary mastery; improve the student's listening skill; enhance student's pronunciation; improve 
student's writing skill; improve student's speaking skill; improve student's reading skill. Also, two themes were used to check the effectiveness of using phrasal verb videos in training students to be independent learners, i.e. effective and ineffective. Dornyei (2007) mentioned that to analyze qualitative data, a process called analytical process was needed. It included some activities, such as "transcribing the data, precoding and coding, growing ideas memos, vignettes, profiles, and other forms of data display, and interpreting the data, and drawing conclusions" ( $p$. 246). Thus, all of the activities mentioned were used in this study, except for the transcribing the data as the interview answers had been given in the written form.

\section{FINDINGS AND DISCUSSION}

\section{Findings}

\section{Benefits of Using English Phrasal Verb Videos}

There were six themes revealed about the benefits of using PVs videos (see table 1).

Improving students' vocabulary mastery came first with the percentage of $100 \%$. It was then continued with enhancing student's pronunciation ability and improving student's listening skill with $67 \%$. Improving student's writing skill was the fourth benefit mentioned by three students participated in this study. At last, Improving student's speaking and reading skills are considered as the least benefits that students got from the activities done using PVs videos.

Table 1. The Benefit of Using English Phrasal Verb Videos

\begin{tabular}{llll}
\hline No & Benefit & $\begin{array}{l}\text { Students' } \\
\text { answers }\end{array}$ & Percentage \\
\hline 1. & $\begin{array}{l}\text { Improve } \\
\text { student's } \\
\text { vocabulary } \\
\text { mastery }\end{array}$ & $\begin{array}{l}\sqrt{ } \sqrt{ } \sqrt{ } \sqrt{ }= \\
\text { Improve } \\
\text { student's } \\
\text { listening skill }\end{array}$ & $600 \%$ \\
2. & $\sqrt{ } \sqrt{ } \sqrt{ }=4$ & $67 \%$ \\
3. & $\begin{array}{l}\text { Enhance } \\
\text { student's } \\
\text { pronunciation } \\
\text { ability }\end{array}$ & $\sqrt{ } \sqrt{ } \sqrt{ }=4$ & $67 \%$ \\
4. & $\begin{array}{l}\text { Improve } \\
\text { student's } \\
\text { writing skill }\end{array}$ & $\sqrt{ } \sqrt{ }=3$ & $50 \%$ \\
Improve \\
5.
\end{tabular}

Is the Use of English Phrasal Verb Videos Effective to Enhance the Student's Independent Learning Skill?

There were two answers provided for students to choose, i.e. effective or ineffective (see table 2). 
Table 2. The effectiveness of using English

Phrasal Verb Videos towards the improvement of Independent learning skill

\begin{tabular}{lll}
\hline No & Students & $\begin{array}{l}\text { Effective/In- } \\
\text { effective }\end{array}$ \\
\hline $\mathbf{1 .}$ & Rafi & E \\
$\mathbf{2 .}$ & Santi & E \\
$\mathbf{3 .}$ & Rara & E \\
$\mathbf{4 .}$ & Claudia & $\mathrm{E}$ \\
$\mathbf{5 .}$ & Jihan & $\mathrm{E}$ \\
$\mathbf{6 .}$ & Aqila & $\mathrm{E}$ \\
\hline
\end{tabular}

Based on the analysis result, all students participated in this study agreed that the use of PVs videos had effectively trained them to be independent learners. The followings are students' answers when they are asked about the effectiveness of PVs activity to improve their independent learning skills.

Yes, I feel easy when I listening to podcast at home and also I feel my skills are improved. (Jihan)

Yes, it is. It trains my independent learning. I still watch Rachel's video sometimes and I'm so thankful to my teacher to gave us a homework by watching the video. It really helps me. (Aqila)

Yes, I hope I can do this activity regularly because to be very honest this activity has a lot of benefits. It helps us to practicing our skills, like listening and writing. (Rara)

Most of the students agreed that the use of PVs videos and the task assigned had triggered them to find other videos. The followings are some students' answers when being asked whether they feel triggered to find other videos or not after doing the activity instructed by the lecturer.

Yes. My pronunciation has improved and I know lots of vocabulary that I never knew before because after I saw the video, I am triggered to looking for a new vocabulary. Also, it triggered me to find another video. (Rafi)

Yes, I do. (Santi)

Yes, but I usually save the video first bcs I don't have time for it. (Jihan)

It was also revealed from the interview that they were motivated to do some other activities for learning English outside the classroom, for example by watching film, listening to the music, and so on. It was confirmed by the participants' comments in their interview.

I sometimes read an English language book, I often listen to music or watch movies in English, and I also join competition like debate or speech in English to practice more. (Rara)

Watching other English Speakers' channel like Oh no Nina (College student who living in America) which related on my hobbies because it avoids me to feel bored while I learning via videos. (Claudia)

Sometimes I read an article from CNN, Time, etc. Read a book which can relate to my major. Watching film although use American or British spell. (Santi) 


\section{Discussion}

Based on the analysis done, it is clear that the use of PVs videos has brought significant impacts to the improvement of the students' English ability. Students reported that the three major benefits they had got after using PVs videos were their vocabulary mastery, pronunciation ability, and listening skill had improved. They also reported that their understanding of the meanings, the pronunciation, and the contexts in which the words should be used had been better than before. As a result, the students knew better how to use the PVs learned in the proper contexts. It was similar to the finding revealed by Almurashi (2016) which showed that the use of video had significantly improved the students' understanding and performance. The result found in this study was also the same with the result mentioned by Mustikawati (2013) in the case of students' better performance. She reported that students who learned using video spoke better than the ones who learned English only with a textbook.

However, there is a little difference between this study result and Mustikawati's result that the improvement of speaking ability was only the least benefit in this study, but it was the major benefit in Mustikawati's study. It happens because this study used PVs videos focusing more on vocabulary, while Mustikawati's study used conversation videos focusing on speaking skill. It was clear that the use of different videos potentially gave different results.

Furthermore, this study also showed that there was a quite significant improvement in the writing skill with the percentage of $50 \%$ due to the use of PVs video and the assignment given by the lecturer. Students reported that their writing skills were trained during the process of PVs learning because they were required to write PVs found in the videos, the meaning of $\mathrm{PVs}$ and the examples of sentences. This writing skill improvement was also found in Lin and Yang's (2011) research. They revealed that the students' writing skill improved after using Wiki technology. It is obvious that the use of technology, learning video, for example, seems to bring benefits for the students' English ability.

Regarding the effectiveness of using PVs videos in training students' independent learning, this study found that this method of teaching had successfully motivated students to do self-study outside the classroom. In other words, it trained students to be independent learners. It was similar to 
the results revealed by Henessy (2005) and Parvin and Salam (2015) in their studies. The students also reported that they were triggered to find other online sources for learning independently. In brief, the use of PVs videos is beneficial not only for improving students' independent learning skills but also triggering students to find more independent learning sources.

The results of this study inform the students and teachers of English that the use of digital media, YouTube video for example, in teaching and learning could be one of the solutions to create an exciting and effective atmosphere for learning English. Students are wellinformed the recommended YouTube channels or sources for their independent learning and they understand well that their independent learning can give significant impacts to their English ability. As a result, they will be more enthusiastic and confident in learning independently outside the classroom. It also gives English teachers information that the use of available digital media can help their works in helping students improve their English skills, which further gives them the insight to create a fun English lesson using various media available.

This study is assumed to have two limitations which need improvement in the future. First, the number of participants which is only six (6) is considered too few. Therefore, the more students participating in the next research are expected to give findings that are better. Second, the result may be better if the researcher uses a mixedmethod in future research. The use of one method in this study seems to limit the researcher's opportunity to generalize the research findings.

\section{CONCLUSION AND SUGGESTIONS}

To conclude, two major findings were revealed in this study. First, there were four main benefits that students get after doing the vocabulary enrichment activity, such as improving their vocabulary mastery, pronunciation ability, listening skills, and writing skills. Second, students considered this activity has effectively triggered them to find new learning sources. It also improved their independent skills in learning English. Another future research is badly needed to ensure another effectiveness of using phrasal verb videos in learning. One of the research topics which is interesting is the impact of using learning videos (Phrasal Verbs Videos) towards the improvement of students' English ability. 


\section{REFERENCES}

Ahmadi, M., R. (2018). The use of technology in English language learning: A literature review. International Journal of Research in English Education, 3(2), 115125

Almurashi, W., A. (2016). The effective use of YouTube videos for teaching English language in classrooms as supplementary material at Taibah University in Alula. International Journal of English Language and Linguistics Research, 4(3), 32-47.

Castillo, S., E. (2017). Fostering conceptual metaphors in vocabulary teaching. Phrasal Verbs in Spanish Secondary Education: A pedagogical implementation. (Doctoral dissertation, University of La Rioja, Logrono, Spain). Retrieved from https://dialnet.unirioja.es/servlet/tesi s? codigo $=122752$.

Dornyei, Z. (2007). Research methods in Applied Linguistics. Oxford: Oxford University Press.

Hennessy, S. Deaney, R. \& Ruthven, K. (2005). Emerging teacher strategies for supporting subject teaching and learning with ICT. Cambridge, UK: University of Cambridge.

Lamb, M. (2002). Explaining successful language learning in difficult circumstances. Prospect, 17(2), 35-52.

Lin, W., \& Yang, S. (2011). Exploring students' perception of integrating Wiki technology and peer feedback into English writing courses. English
Teaching: Practice and Critique, 10(2), 88103. https://eric.ed.gov/?id=EJ944900.

Mart, C., T. (2012). How to teach Phrasal Verbs. English Language Teaching, 5(6), 114-118.

Mattarima, K., \& Hamdan, A. R. (2011). The teaching constraints of English as a foreign language in Indonesia: The context of school based curriculum. Sosiohumanika, 4(2), 287-300.

Mustikawati, A. (2013). The effectiveness of using video in teaching speaking for the eighth grade students of SMP $N 1$ Manisrenggo (Undergraduate thesis, Yogyakarta State University, Yogyakarta, Indonesia). Retrieved from https:/ / eprints.uny.ac.id/25728/1/Ar um\%20Mustikawati\%2007202241067.p df.

Novera, I. A. (2004). Indonesian postgraduate students studying in Australia: An examination of their academic, social, and cultural experiences. International Education Journal, 5(4), 475-487.

Parvin, R. H., \& Salam, S., H. (2015). The effectiveness of using technology in English language classrooms in government primary schools in Bangladesh. FIRE: Forum for International Research in Education, 2(1), 47-59.

Vasbieva, D., G. (2015). Teaching strategy on learning of English Phrasal Verbs by Economics Major Students in Rusia. XLinguae Journal, 8(3), 57-65. 